\title{
МОДЕРН ТА ПОСТМОДЕРН: ОПОЗИЦІЯ ЧИ СПАДКОВІСТЬ?
}

\section{С.В. Куцепал}

Будь-яка нова епоха, що проголошується в культурі, мистецтві або науці, викликає необхідність визначити зміст попереднього циклу, оскільки нове завжди пов'язане з пам'яттю про минуле, визначенням хронологічних рамок та генеалогії попереднього проміжку часу. Постмодерн, будучи парадигмою сучасної філософії, звісно, не виникає 3 нічого: він екзістенційно-онтологічно пов'язаний з філософією Модерну, хоча й потрактовує основні положення останньої досить своєрідно.

Перш ніж аналізувати ставлення французьких філософів до модерного спадку та до визначення сутності й значення модерної філософiї, необхідно зробити одне методологічне зауваження щодо творчості I. Канта, ідеями якого Ж. Дельоз, Ф. Гваттарі, Ж.-Ф. Ліотар, Ж. Дерріда надзвичайно активно послуговуються. Таке шанобливе ставлення до німецького філософа грунтується на усвідомленні його пріоритету у визначенні завдань філософії, стратегічної спрямованості останньої на критику розуму.

Як відомо, І.Кант досить високо оцінював епоху Просвітництва, вважаючи її межею, кордоном, що поділяє історію людства на два етапи - «неповноліття» та «повноліття». Особливо імпонує французьким мислителям кантівське гасло: «Людино, май мужність вільно користуватися своїм розумом!» [4, с.127], котре стає для них керівною настановою, оскільки вони піддають критиці розум з усіх мислимих позицій - оспівуючи безум (М. Фуко) або визначаючи пріоритетне положення «вільного, веселого шизоїда» у шаленому світі кінця ХХ століття (Ж. Дельоз та Ф. Гваттарі). Як бачимо, учні, протестуючи вслід за своїм вчителем проти духовного, морального, інтелектуального, владного

Актуальні проблеми духовності: зб. наук. праць / Ред.: Я.В. Шрамко

Вип. 10. - Кривий Ріг, 2009, 3-13 
нагляду, залишили його далеко позаду, оскільки потрактовують будьякі гранднарративи як вияви волі до влади, як прояви насильства. Тому в порівнянні зі своїми послідовниками I. Кант деколи постає не критиком, а, як це не парадоксально, майже апологетом того розуму, котрий не має самостійного статусу, оскільки «червоною ниткою», головним мотивом кантівської критичної філософії $є$ оптимістична віра у творчу, інтелектуальну особистість, у конструктивні потенції людського розуму, тоді як французькі філософи радше репрезентують позицію «світоглядного розчарування» (В.С.Лук'янець), що відкидає можливість оптимістичного розв'язання нагальних потреб людства (від загрози екологічної кризи і до привиду міжнародного тероризму, що особливо активізувався останнім часом, зайнявши місце іншої сумновідомої примари, яка століттями блукала манівцями Європи). Як слушно зазначає В.С.Лук'янець, «ініціатори постмодерну шукають відповіді на філософські проблеми, які стосуються не тотальної приватизації Всесвіту, а перспектив самозбереження в ньому посттоталітарної соціальності» $[6$, с. 11$]$.

Найперші асоціації, що спадають на згадку при характеристиці модерної філософії, - це раціоналізація, емансипація людського Я, віра в надзвичайне призначення людини, котра завдяки своєму розуму та діяльності здатна стати володарем природи, а також сприйняття всього існуючого з точки зору трансцендентального суб'єкта, який прагне критично обгрунтувати сутність людського існування. Чи не центральним об'єктом філософської рефлексії стає сама людина, відносно якої світ має репрезентувати себе, перетворитися на значущий для суб'єкта образ. Ще одна особливість модерної філософії - віра в силу науки, в її здатність створити таку метатеорію, котра абсолютно повно пояснить усе існуюче. До речі, саме на цьому бастіоні модерна парадигма була піддана першим руйнівним ударам, завданим відкриттями так званої некласичної науки, здійсненими Геделем, Бором, Гейзенбергом, а також синергетичними постулатами.

Наступне розчарування чатувало на теоретиків Модерну на теренах соціальної філософії, де зазнала краху ідеологія соціалізму та комунізму, була втрачена віра в можливість практичного втілення соціальних утопій, у здатність індустріальних суспільств, особливо західного типу, до безмежного самозбагачення та самоускладнення.

Найстрашнішим ударом стали катастрофи й трагедії минулого ХХ ст. (від революцій початку віку до розвалу тоталітарних держав у 90-ті роки), викликані переважанням політичного над соціальним, коли всі соціальні інститути, усі великі цінності та глобальні цілі, 
що створювалися в попередні епохи, поступово втратили свій зміст. Слушною видається думка А.Турена про те, що найбільш наочною формою панування політичної дії над соціальною є тероризм, оскільки він формується на перехресті старих соціальних рухів, які стали більш ідеологічними, ніж практичними, та реакцій на кризу держави. «Тероризм сам по собі-як і партизанська війна в інших ситуаціях цілком протилежний класовій чи масовій дії. Він свідчить, навпаки, про надмірне роз'єднання між теоретичним закликом до вже зниклого руху та надмірно інституціалізованими вимогами» [7, с. 26]. Тому ще страшнішим видається теракт, котрий відбувся 11 вересня 2001 року в США. Гірка моторошна іронія полягає в тому, що ще в 1976 р. французький філософ Ж. Бодрійяр назвав символом епохи симулякрів (а саме так він визначав сучасність) саме ці дві вежі WTS. «Сам факт наличия этих двух идентичных башен означает конец всякой конкуренции, всякой оригинальной референции. Чтобы знак обрел чистоту, он должен продублировать себя, самодублирование знака как раз и кладет конец тому, что он означал» $[1$, с. 146].

Епоха модерну розірвала сакральний світ, котрий був таким зручним та зрозумілим, відокремила природне від божественного, позбавила світ єдності, не замінивши цю єдність нічим рівноцінним. Зійшовши з небес на землю, суб'єкт не знайшов там справжнього притулку, загубився у світі об'єктів та речей, котрими маніпулюють різноманітні технології. Головними менеджерами цього технізованого світу стали раціоналізація та суб'єктивація.

Наслідком таких потрясінь стає усвідомлення людством того, що воно є заручником тих деструктивних сил, того джина з пляшки, котрого вивільнили науково-технічні досягнення та ідеологія тоталітаризму. Декартівський володар світу та приборкувач природи потрапляв то в окопи світових війн, то в бараки концентраційних таборів, то у селища поблизу Чорнобиля, поки нарешті не опинився 11 вересня 2001 р. у приміщеннях Всесвітнього торгівельного центру. Саме ці причини обумовили й обумовлюють необхідність досягнення адекватного розуміння екзистенційної ситуації, до якої потрапила західна цивілізація на межі тисячоліть.

«Доба Постмодерну - це час, коли людське життя виходить із-під диктатури розуму, приборканого вічними істинами метафізики, й висуває йому свої вимоги. Найпершою нормою етики Постмодерну стає не метафізична істина, а повнота життя. Найвище життєствердження мислителі постмодерну вбачають у сприянні максимальному зростанню волі до життя. Вони переконані, що людина тільки тоді реалізує 
сенс свого життя, коли вільно стверджує все, що в неї є» [6, с. 13].

Варто зазначити, що ставлення сучасних французьких мислителів до феномену постмодерну (як, до речі, і Модерну) не є однозначним. На підтвердження даного положення наведемо концепцію А. Турена, одного з провідних соціологів, творчість якого викликає на Заході не меншу увагу, ніж праці Ж. Дерріда чи Ж. Дельоза, і твори якого так само активно перекладаються. А. Турен має власну точку зору і на Модерн, і на Постмодерн, котра грунтується на розумінні суспільства як поля конфліктної комунікації множини різнопланових дієвців (під дієвцем розуміється суб'єкт у його конкретно-історичних іпостасях, котрий у різні історичні періоди втілюється в різні соціальні утворення класи, соціальні рухи, політичні об'єднання). Простежуючи долю ідеї модерності, мислитель прагне віднайти шляхи розв'язання проблем та суперечностей, властивих сучасному людству. Французький соціолог переконаний, що сьогодні існує досить глибока, але все ж таки обмежена (а зовсім не глобальна!) криза модерності, яка засвідчує про зникнення соціального еволюціонізму, здатного враховувати всі аспекти соціального життя та його перетворень, тобто занепадає матеріалістична соціальна думка, придушена технологією та раціоналізацією, а ідея постмодерного суспільства - це ніщо інше, як гранична ознака кризи індустріальної культури.

Двадцяте століття характеризується А. Туреном як таке, де модерний світ розуму все більше потрапляє у залежність від різноманітних типів політики модернізації та націоналістичних диктатур. Зазначений стан речей викликає критику модерності з боку інтелектуалів, охоплених відчуттям катастрофи, безглуздості, зникнення дієвців історії.

Початок тотальної критики модерного суспільства та його культури А. Турен убачає в діяльності філософів-франкфуртців, оскільки саме вони розцінюють світ, де живуть, як царину занепаду об'єктивного розуму, як відмову від раціоналістичного світобачення. Ідеї замінюються на ідеології (нацизму, сталінізму, тоталітаризму тощо), а результатом цього стає зникнення сполученості індивіда з суспільством. «Модерна людина вже не поводиться згідно з універсальними правилами розуму» [7, с. 41].

А позаяк природа, як відомо, «не терпить порожнечі», то індивідуальний суб'єкт, що відокремлюється від розуму, потрапляє у залежність від економічної або політичної влади. Відбувається розчаклування модерного світу (М.Вебер), котре не вичерпується лише зникненням сакрального та загибеллю міфів, - головна небезпека полягає у втраті єдності світу. Як стверджує А. Турен, «історія модерності 
$\epsilon$ історією повального, просто невідворотного розриву між індивідом, суспільством та природою» [7, с. 42]. Виникає постмодерне суспільство, істотними ознаками якого французький соціолог визначає ностальгію за Буттям, ринкове споживання, владу підприємництва, злет націоналізмів, повний розпад інструментальної раціональності. «Розпад економічних стратегій і побудова певного типу суспільства, культури i особистості відбувались дуже швидкими темпами, саме ця побудова дала ім'я та зміст ідеї постмодерності. Якщо модерність поєднувала прогрес і культуру, протиставляючи традиційні культури чи суспільства їхнім модерним відповідникам і пояснюючи будь-який соціальний і культурний факт його місцем на шкалі традиція - модерність, то постмодерність роз'єднує те, що було поєднаним» [7, с. 72].

Незважаючи на загалом негативне ставлення до постмодернізму, А. Турен, однак, визнає останній чимось значно більшим, ніж просто інтелектуальною модою, оскільки постмодернізм стає продовжувачем тієї критики Ratio, яку розпочали Маркс, Ніцше та Фрейд, більше того, «він $є$ підсумком тривалого інтелектуального руху, що майже завжди протиставляє себе технічній та економічній модернізації, якій у минулому столітті не було присвячено жодної значної інтелектуальної праці» [7, с. 73].

Постмодернізм відкидає функціональну диференціацію між царинами соціального життя (мистецтво, економіка, політика), відмовляється визнавати їхню взаємодоповнюваність, маніфестує неможливість використання сферами соціального життя інструментального розуму. Якщо раніше домінуючою була картина світу, де людина була розташована «перед світом», а тому мала здатність розуміти його та відтворювати у певних образах, то людина постмодерної картини світу опиняється всередині світу, вона позбавлена дистанціювання, замінником якого постає мережа комунікацій.

Ще більш радикальну критику постмодерну знаходимо в концепціях Ж.Бодрійяра та Ж.Ліповецьки, котрі взагалі проголошують настання ери розпаду соціального.

Для відомого своїми соціологічними та філософськими розвідками Жіля Ліповецьки характерне прагнення розкрити сутність постмодернізму шляхом визначення та аналізу тих життєвих настанов, котрі виступають суттєвими характеристиками сучасності, найяскравішими серед яких виявляються зваблення, cool (індиферентність), нарцисизм, відступництво та ескапізм. Виникнення постмодернізму пов'язується вченим з появою ери порожнечі (спустошення), що приходить на зміну ері споживання, з якою співвідноситься існування та розвиток мо- 
дернізму. Саме протягом ери споживання набирає обертів процес персоналізації, апофеоз якого припадає на період постмодернізму. «Эра потребления десоциализует индивидов и, соответственно, социализирует, в силу логики удовлетворения потребностей и необходимости в информации; это социализация без насилия, социализация мобильного типа» [5, с. 165$]$.

Важливо звернути увагу на два значення французького слова personne, яке, по-перше, позначає людину, особу; по-друге, слугує для позначення будь-кого, нікого. Завдяки цьому персоналізація тлумачиться Ж. Ліповецьки одночасно і як індивідуалізація, і як спустошення, перетворення у ніщо.

Завдяки тому, що споживання являє собою відкриту та динамічну структуру, воно здатне звільнити людину від соціальної залежності, прискорити процеси асиміляції та відчуження, створити індивідів, котрі не здатні приймати однозначні рішення, знівелювати рівні життя. Усе це призводить до появи максимальної індивідуалізації.

Суттєвою ознакою постмодернізму Ж.Ліповецьки визнає наявність в останньому двох логік - дисциплінарної та ієрархічної. Починаючи з кінця XIX ст. (а саме цей проміжок часу соціолог визначає початком ери споживання), дисциплінарна тенденція починає домінувати й утримує своє панування до початку $60-\mathrm{x}$ років минулого століття, коли на зміну модерному суспільству прийшло постмодерне. «Постмодернистское общество возникло в тот момент, когда западное общество стало все чаще отвергать единообразные структуры и создавать персонализированные системы на основе потребности, выбора, связи, информации, децентрализации, участия. Постмодернистская эпоха ни в коем случае не является сверхчувственной; напротив, это спокойная, с элементами разочарованности, фаза модернизма, направленная к чрезмерной гуманизации общества, развитию неосязаемых структур, модулированных в зависимости от индивида и его желаний к нейтрализации классовых конфликтов, охлаждению разгоряченного революционного воображения, ее сопровождает растущая апатия, десубстанциализация нарциссов, частичная реабилитация прошлого» [5, с. 168].

Ж. Ліповецьки полемізує з Ж. Бодрійяром та Ж.-Ф. Ліотаром, котрі відстоюють тезу про принципову відмінність постмодерну від попередньої фази розвитку суспільства, хоча й роблять це в ім'я різних цілей (або заради невизначеності та симуляції, або заради відмови від метанарративів). Для Ліповецьки постмодерн уявляється не відірваним від модернізму, а, навпаки, постає утвердженням однієї з суттєвих тенденцій останнього - процесу персоналізації і, відповідно, по- 
ступовим скороченням дисциплінарного процесу. «Постмодернистское общество, возводя процесс персонализации в разряд господствующего образа жизни, реализует особенности модернистского мира» [5, с. 169].

Одне з основних завдань, що мають бути вирішені постмодернізмом, - зняття суперечності між традиційністю та модерном. Саме тому для Ж.Ліповецьки картезіанське Cogito не зникає з горизонту філософствування, а породжує нову картину світу, взасадничену на таємницях людського існування, таку собі енігматичну реальність, котра потребує розшифрування, розкодування за допомогою персоналізації, має як позитивну, так і негативну сторони. Перша полягає в тому, що процес персоналізації відповідає структурі гнучкого суспільства, заснованого на інформації та заохочуванні потреб індивіда, а друга виражається в тім, що процес персоналізації обумовлює злам дисциплінарної соціалізації. Таким чином, процес персоналізації постає в якості нового способу організації та орієнтації суспільства, нового способу управління подіями (максимум бажання, мінімум примусу). «Освобожденное из „гетто“ надстройки и идеологии, обольщение является преобладающим началом в социальных отношениях, глобальным принципом организации в обществе изобилия» [5, с. 34].

Персоналізація впроваджується в життя за допомогою різних механізмів, серед яких одним з найважливіших Ж. Ліповецьки визнає зваблювання, котре пронизує собою всі рівні постмодерністського суспільства - від політики й до приватного життя.

Зваблення не має нічого спільного з хибним зображенням та відчуженням свідомості, оскільки являє собою те, що влаштовує наш світ та перетворює його відповідно до систематичного процесу персоналізації, робота якого спрямована на збільшення та урізноманітнення пропозицій, на легітимацію вільного вибору. Посилює роль зваблення й сучасний тип життя, визначений Ж. Ліповецьки як життя без категоричних імперативів, котре можна будувати згідно з індивідуальними устремліннями і яке відповідає ері комбінацій, варіантів та незалежних формул. «Обольщение - это логика, которая пробивает себе дорогу, которая больше ничего не щадит и при этом осуществляет постепенную, толерантную социализацию, цель которой - персонализировать и психологизировать человека» [5, с. 40].

Персоналізація епохи постмодерну створює новий тип людини, новий персонаж онтологічного театру - Нарциса, пригнобленого самим собою, замурованого у власній скляній капсулі, що має ще одне ім'я cool-людина. «Cool-человек не является ни пессимистическим декадентом Ницше, ни угнетенным тружеником Маркса; он скорее напоми- 
нает телезрителя, пытающегося „прогнать“ одну за другой вечерние программы; потребителя, наполняющего свою кошелку, отпускника, колеблющегося между пребыванием на испанских пляжах и жизнью в кемпинге на Корсике» [5, с.68]. Нарцис позбавлений здатності відчувати та хвилюватися, тому його карою стає духовне спустошення, відсутність як чужих, так і власних пристрастей, неможливість відчути себе «на сьомому небі».

Символом сучасної цивілізації Ж. Ліповецьки називає пустелю, той трагедійний образ, що $є$ втіленням метафізичних розмислів про небуття. «Пустыня побеждает, в ней мы видим абсолютную угрозу отрицательного начала, знак смертоносной работы XX века, которая будет продолжаться до его апокалиптического конца» [5, с. 58]. Але Нарцис, позбавлений здатності відчувати та перейматися, не сприймає пустелю як те, що асоціюється з небуттям та смертю, вона уявляється йому досить густо заселеною. Населення пустелі різноманітне: це маргінали, дезертири, бунтарі, усі ті, хто є «романтиками» або «дикунами», тому пустеля онтологічно наповнена, має величезний енергетичний потенціал, вона - простір без початку та кінця. Отже, соціальна пустеля заселена, але її населення веде кочовий спосіб життя, воно не прив'язане до певної території і саме в цьому проявляється одна з основних тенденцій постмодернізму, випещена та оспівана у номадології Ж. Дельоза та Ф. Гваттарі.

На думку іншого французького філософа Ж. Бодрійяра, сучасний етап історії людства характеризується втратою соціального та реального. Копії замінюють оригінали, симулякри владарюють над світом, перетворюючи реальність на гіперреальність. Як іронічно зазначає Ж. Бодрійяр, людство живе тим, що вже було колись прожите, а зараз лише відтворюється, при цьому ніяка нова реальність не вибудовується.

Філософ детально аналізує предметно-зображувальний образ-знак, у генезі якого виділяються чотири етапи: 1) знак відображає основуреальність; 2) приховує та спаплюжує основу-реальність; 3) зауважує відсутність основи-реальності; 4) немає жодного відношення до будьякої реальності, тому залишається лише чиста видимість, самоподоба, симулякр. Наслідком цього стає те, що реальність визнається надлишковою, замість неї- гіперреальність, пов'язана з неупорядоченим народженням образів, які поєднуються між собою без будь-якого зв'язку 3 реальністю чи смислом.

Сучасність - це той проміжок часу, що настає після закінчення оргії, при цьому остання розуміється як момент звільнення в будь-якій 
сфері. Дійсно, важко не визнати, що минуле століття справді нагадувало оргію - оргію матеріального, раціонального та ірраціонального, сексуального, критичного та антикритичного, оргію всього того, що пов'язано з хворобами зростання. Усі табу та заборони було знято, таємниці розкрито, обмеження скасовано. Тотальне звільнення, результатом якого стала порожнеча, позаяк усі прояви звільнення залишилися позаду і нас хвилює лише передбачення всіх можливих результатів здійснення звільнення.

У процесі звільнення речі, знаки, дії позбавилися своїх ідей та концепцій, походження та призначення, але водночас вони стають на шлях нескінченого самовиробництва. Такі соціальні феномени, як економіка, політика, сексуальність, перетворюються на трансекономіку, трансполітику, транссексуальність. Відбувається змішання та взаємопроникнення категорій, захоплених коефіцієнтом зверхності, рекорду, інфантильного самоподолання. «Каждая категория совершает фазовый переход, при котором ее сущность разжижается в растворе системы до гомеопатических, а затем до микроскопических доз вплоть до полного исчезновения, оставляя лишь неуловимый след ,словно на поверхности воды“» $[2$, с. 15$]$.

Життя суспільства скеровується законом змішування жанрів - усе стає політичним, сексуальним, естетичним. Наслідком такого змішування стає те, що зазначені категорії втрачають свою специфіку й розчиняються в інших категоріях.

Втрата соціального відбувається також внаслідок схильності масової свідомості до імплозії, тобто вбирання, втягування в себе будь-якого впливу, коли суб'єкт впливу не дає на нього ніякої відповіді. Маса, вважає Ж. Бодрійяр, не володіє ні атрибутом, ні предикатом, ні якістю, ні референцією, тобто вона не має «соціальної реальності». Маса не постає більше як «дзеркало соціального», оскільки не віддзеркалює останнє. Більше того, стикаючись з масами, це «дзеркало соціального» розбивається. Замість того, щоб бути відображенням соціального, маса починає виконувати функцію «чорної дірки», котра відхиляє, викривляє будь-які потоки енергії, що зближуються з нею, перетворюється на безодню симуляції всіх втрачених референцій. Одним із найзапекліших ворогів маси стає смисл. Загроза останнього полягає в тому, що маса відчуває терор схематизації, прихований за гегемонією смислу, - а тому намагається опиратися йому, переводити артикульовані дискурси в площину ірраціонального та безосновного, тобто у площину видовища, котре не зачіпає індиферентну масу.

Мовчазна більшість, що домінує у сьогоднішньому соціумі, є єди- 
ним референтом репрезентації. «Массы не являются референтом, поскольку уже не принадлежат порядку представления. Они не выражают себя - их зондируют. Они не рефлектируют - их подвергают тестированию. Политический референт уступил место референдуму (организатор постоянного, никогда не прекращающегося референдума средства массовой информации). Однако зондирования, тесты, референдум, средства массовой информации выступают в качестве механизмов, которые действуют уже в плане симуляции, а не репрезентации. И ориентированы они уже на модель, а не на референт» [3, с. 26].

Мовчання маси досить специфічне, адже воно накладає заборону на те, щоб про нього говорили від його імені. Окрім цього, мовчазна більшість не має представників, оскільки маси вже не являють собою інстанцію (на відміну від класу або народу) і не є суб'єктом, а тому не можуть бути відсторонені від самих себе. Маса - це царина поглинання та імплозії, ірраціональна безодня, що втягує в себе соціальне. Два століття посиленої соціалізації закінчилися досить сумно: «Ранее властвовало социальное - и его рациональная сила разрушала символические структуры, сегодня на первый план выходят mass media и информация - и их ,иррациональным“ неистовством разрушается уже социальное. Ибо благодаря им мы имеем дело именно с ней - этой состоящей из атомов, ядер и молекул массой» [3, с. 32].

Однією з основних властивостей маси Ж. Бодрійяр вважає її парадоксальність, котра виражається, по-перше, в тому, що маса виступає одночасно і об'єктом, і суб'єктом симуляції, тому, відповідно, здатна й до гіперсимуляції; i, по-друге, в тому, що маса не є ні суб'єктом, ні об'єктом, оскільки не може бути носієм автономної свідомості і не піддається ні впливу, ні розумінню в термінах елементів, відношень, структур та сукупностей. Будь-який вплив на масу, потрапляючи у поле її тяжіння, починає рухатися по колу, проходить стадії поглинання, відхилення та нового поглинання. Завдяки цим особливостям маса являє собою парадоксальний та граничний стан соціального. Соціальність замінюється театральністю, сценою, де діють політичні актори. Маса залюбки починає виконувати роль глядача, головна увага якого зосереджується не на історичному та політичному з властивою їм дієвістю, а на буденному, плинному житті. «Моделью восприятия политической сферы служит восприятие матча, художественного или мультипликационного фильма. Точно так же, как зрелищем на домашнем телеэкране, население заворожено и постоянными колебаниями своего собственного мнения, о которых оно узнает из ежедневных газетных публикаций результатов зондажа. И ничто из этого не рождает ника- 
кой ответственности. Сознательными участниками политического или исторического процесса массы не становятся ни на минуту» [3, с. 46].

Позбавлені структури, інертні маси, заперечуючи соціальне, тим часом діють за його законами, ще більш розхитуючи й без того нестійкий каркас соціального. Більше того, сутність нашої сучасності вбачається Ж.Бодрійяру не у боротьбі класів чи у взаємодії меншостей, а саме у «глухом, но неизбежном противостоянии молчаливого большинства навязываемой ему социальности, именно в этой гиперсимуляции, усугубляющей симуляцию социального и уничтожающей его по его же собственным законам» [3, с. 57$]$.

Соціум, влада породили мовчазну більшість, котра не $є$ ні сутністю, ні соціологічною реальністю. Заснована на інерції, а не негативності, маса не помічає революцію, їі ідеалом стає інволюція, абсолютне виключення революційних лозунгів про активну роль свідомості. Примари, породжені марксизмом, відпочивають, головними діючими особами ери порожнечі виступають симулякри...

\section{1 Бібліог рафія}

[1] Бодрийлр Ж. Символический обмен и смерть.-М.: Добросвет, 2000.

[2] Бодрийлр Ж. Прозрачность Зла: Сб. эссе.-М.: Добросвет, 2000.

[3] Бодрийяр Ж. В тени молчаливого большинства, или Конец социального. - Екатеринбург, 2000.

[4] Кант И. Сочинения / На нем. и рус. яз. / Н. Мотрошилова, Б. Тушлинг (подгот.) - М.: Kami, 1994.-T. 1: Трактаты и статьи (1784-1796).

[5] Липовецки Ж. Эра пустоты. Эссе о современном индивидуализме / Пер. с франц. В.В. Кузнецова. - СПб.: Владимир Даль, 2001.

[6] Лук'янець В. Постмодерн: філософія світоглядного розчарування // Філософські обрії. - Вип. 7. - К. - Полтава, 2002. - С. 3-15.

[7] Турен А. Повернення дієвця. - К.: Альтерпрес, 2003. 